\title{
Chromosome count, meiotic abnormalities and pollen sterility in Lahaul sweetvetch (Hedysarum astragaloides Benth. ex Baker, Fabaceae), an endemic and threatened species from India
}

\author{
Puneet Kumar ${ }^{1 *}$, Pawan Kumar Rana ${ }^{2}$, Vijay Kumar Singhal ${ }^{2}$, Harminder Singh ${ }^{1}$, Bhupendra Singh \\ Kholia $^{1}$ \\ ${ }^{1}$ Botanical Survey of India, Northern Regional Centre, Dehradun, Uttarakhand, India \\ ${ }^{2}$ Department of Botany, Punjabi University, Patiala, Punjab, India
}

\begin{abstract}
Male meiotic studies were carried out on eight different accessions of Hedysarum astragaloides Benth. ex Baker (Fabaceae), an endemic and threatened species of northwest Himalaya, India. Although genetic factors such as meiosis, chromosome number, and ploidy level may be causative for the evolution, endemism, rare distribution or even extinction of the species, no detailed information exists. Keeping this in mind $H$. astragaloides has been studied cytologically. Male meiotic investigations revealed diploid level $(2 n=2 x=14)$ for species and normal meiotic course in the accessions from the Manali Hills resulting in nearly 100\% pollen fertility. However, the accessions scored from the Manimahesh Hills and Pangi Valley depicted inter-pollen mother cell transfer of chromatin material and structural heterozygosity for reciprocal translocations. Consequent upon these meiotic anomalies, some pollen sterility (21\%) resulted. On account of this sweeping genetic outcome, the incidence of anomalies such as this in an endemic and threatened species warrants grave consideration. It is sensible to conclude that conservation measures should include the collection of germplasm from the localities where plants are meiotically stable with high gametic fertility, to ensure good germination and healthy plants for future use. Seeds from meiotically normal individuals should be given priority for inclusion in seed banks.
\end{abstract}

Key words: cytomixis, endemic, Hedysarum astragaloides, meiosis, pollen sterility

\section{Introduction}

Hedysarum astragaloides Benth. ex Baker (Fabaceae) also known as 'Lahaul sweetvetch' is an endemic and threatened species of northwest Himalaya, India (Sanjappa 1992, Aswal and Mehrotra 1994, Singh et al. 2002, Lal et al. 2014). Earlier, the species was considered as "Rare" in the Red Data Book of Indian Plants (Pramanik 1988). Recently it was assessed as Vulnerable (VU) and Endangered (EN) according to IUCN categories (Lal et al. 2014). In India the species was earlier reported only from Chenab Valley - Kishtwar (Jammu and Kashmir) and Lahaul-Spiti district (Himachal Pradesh). Recently, one of the authors reported it for the first time from Kullu and Chamba districts (Kumar 2010) as an extended distribution; therefore, these localities having this species were not mentioned in the previous floras (Dhaliwal and Sharma 1999; Singh and Sharma 2006). While ad- dressing taxonomic anomalies in $H$. astragaloides (Lal et al. 2014) also confirmed its extended distribution in Kullu and Chamba districts of Himachal Pradesh.

$H$. astragaloides is a perennial, prostrate to erect herb with appressed silky hairs on slender to robust stems (Fig. 1a). Leaves alternate with linear-oblong, obtuse, mucronate leaflets which are glabrescent above and pubescent below. The species can be easily recognized in the field from its characteristic long dense raceme having light pink to red flowers (Fig. 1b) which appear in the June and turn pale yellowish white after anthesis. The citation of yellow flowers in all previous taxonomic works (Baker 1876, Fedtschenko 1902, Ohashi and Tateishi 1975, Ali 1977, Chowdhery and Wadhwa 1984, Pramanik 1988) shows that perhaps the authors had not observed the species in nature, as was rightly pointed out by Lal et al. (2014). The species grows on moist

* Corresponding author, e-mail: puneetbotcyto@gmail.com 


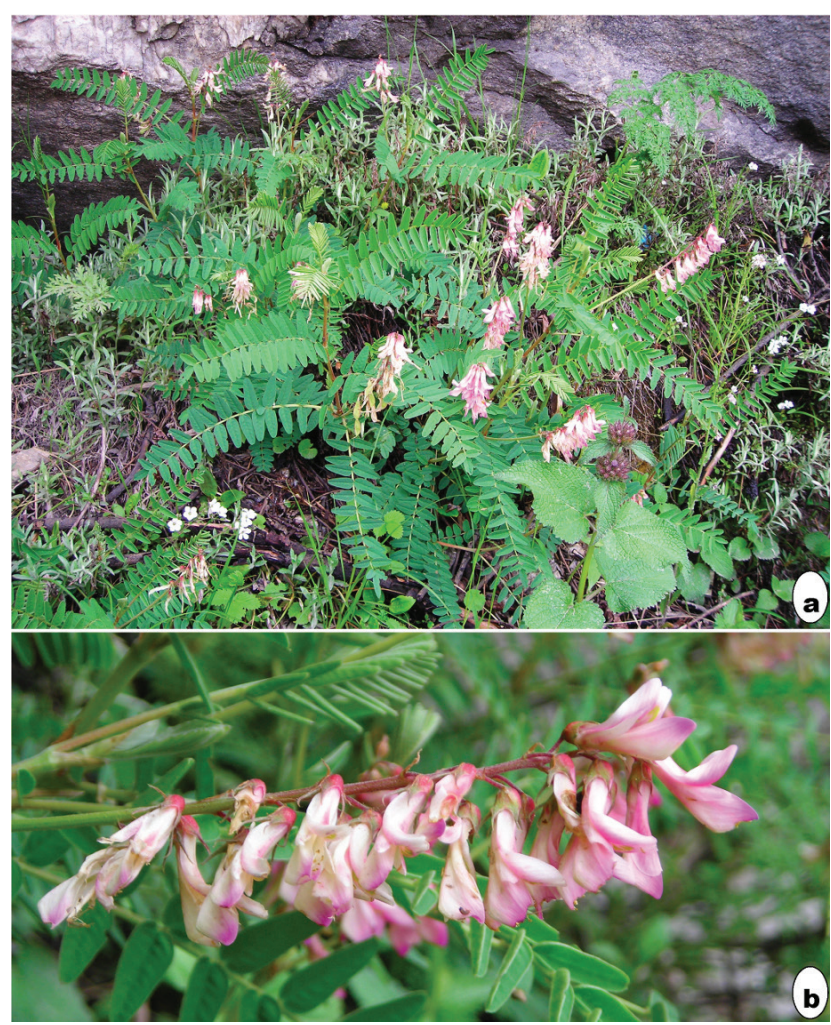

Fig. 1. Hedysarum astragaloides growing in its natural habitat (a); an inflorescence, raceme showing light pink-purple flowers (b).

shady and grassy slopes on mountains between altitudes of 2450-4270 m, and under great threat of extinction due to habitat destruction caused by grazing and landslides (Lal et al. 2014). Except for taxonomic and distributional assessment studies, no information on the genetic variability is available about $H$. astragaloides, and not even primary data such as chromosome number exist for this endemic and threatened species. Generally, it has been suggested that a species with a narrow distributional range possesses a low level of genetic diversity and is at more risk than the widely distributed species. Rare, endangered, threatened and endemic species are increasingly being accorded high priority by world conservation agencies envisaging long-term goals for conservation programmes. Thus, evaluation of the genetic and reproductive potential of such endemic and threatened species from unexplored areas is very significant because the data generated can be used to develop a future conservation strategy. Scientists have long been attracted towards rare, endangered threatened and narrowly endemic species. In current years, this attraction has turned to urgency, as constantly more species dwindle toward loss (Gitzendanner and Soltis 2000). These rare, endangered threatened and endemic species are in danger to lose the genetic variation through genetic drift in undersized populations. The conservation strategies of such taxa urgently require an understanding of their biology and other factors, including genetic variability (allele, gene, chromosome number, meiotic behaviour and ploidy level). The collecting of information on population genetic make-up of rare species has become a general prologue to conservation planning (Archibald et al. 2001). Knowledge of genetic diversity at any level such as allele, gene, chromosome number, meiotic behaviour and ploidy may prove to be pivotal for designing conservation strategies for threatened and endangered species so as to guarantee sustainable survival of populations and to preserve their evolutionary potential. Even a little information about the species at any diversity level of the organisms under study can help scientists and managers form strategies to preserve and protect the diversity. Information on chromosome numbers and ploidy is of the essence for the elucidation of taxonomic affiliations and modes of their evolution such as crossing barriers or historical and contemporary gene flow (Levin 2002, Stuessy 2009, Sánchez-Jiménez et al. 2012). More importantly such basic data become strategically important during implementation of in-situ and ex-situ conservation actions like resource acquisition and the maintenance and reintroduction of species. Chromosome surveys provide a useful insight into population structure of both rare and common plants. In an endeavour to analyze and evaluate chromosomal diversity among flowering plants of the high hills of the northwest Himalayas (India), and through random exploratory surveys, we found a small number of individuals of $H$. astragaloides at two different localities, the Chamba and Kullu districts of Himachal Pradesh. Thus, the current investigation is an effort to study this endemic, vulnerable and threatened species from a cytogenetic point of view. The study also correlates the occurrence of cytomixis with that of gametic sterility and its plausible effects.

\section{Materials and methods}

Flower buds for meiotic investigations of $H$. astragaloides were collected from the plants growing in the wild in Shiv Gharat, 3360 m, Manimahesh Hills; Chask Bhatori, Pangi Valley, $3600 \mathrm{~m}$ and Manali Hills on the way to Rohtang Pass, $3280 \mathrm{~m}$. In total, eight accessions were investigated (four from Shiv gharat, one from Chask Bhatori and three from Manali Hills) (Tab. 1). The cytologically analysed plants were identified using regional floras and compared with the specimens deposited at the Herbarium of Botanical Survey of India (BSD), Northern Regional Centre, Dehradun. The voucher specimens of all selected/studied plants were deposited with the Herbarium of the Department of Botany, Punjabi University, Patiala (PUN). Flower buds of proper size were collected from wild randomly selected plants and fixed in Carnoy's fixative for a minimum of $24 \mathrm{~h}$ at room temperature and later transferred for storage in $70 \%$ ethanol and kept in refrigerator. Anthers were squashed in $1 \%$ acetocarmine stain for meiotic preparations according to Belling (1921). On average 50-100 pollen mother cells (PMCs) were analyzed per each plant at diplotene/diakinesis/metaphase-I to study the meiotic behaviour. On average $25-50$ cells were analysed at anaphase I/II per plant to study the distributional pattern of chromosomes/chromatids. For determination of percentage of pollen stainability, the pollen grains were stained in 1: 1 glycerine: acetocarmine mixture (Marks 1954) 
Tab. 1. Locality, habitat, latitude and longitude, altitude, accession number (PUN), meiotic chromosome number (n), ploidy level, meiotic behaviour, pollen sterility of different accessions in Hedysarum astragaloides Benth. ex Baker.

\begin{tabular}{|c|c|c|c|c|c|}
\hline Locality, habitat, geographical coordinates & $\begin{array}{c}\text { Accession } \\
\text { number }\end{array}$ & $\mathrm{n}$ & $\begin{array}{c}\text { Ploidy } \\
\text { level }\end{array}$ & Meiotic behaviour & $\begin{array}{c}\text { Pollen } \\
\text { sterility \% }\end{array}$ \\
\hline $\begin{array}{l}\text { Manimahesh hills, Shiv Gharat, Chamba district, } \\
\text { Himachal Pradesh, moist shady and grassy slopes on } \\
\text { mountains, } 32^{\circ} 24^{\prime} 57^{\prime \prime N}, 76^{\circ} 37^{\prime} 2^{\prime E} \text {, Alt.: } 3360 \mathrm{~m}\end{array}$ & $\begin{array}{l}51300 \\
51301 \\
51302 \\
51303\end{array}$ & 7 & $2 \times$ & $\begin{array}{l}\text { Inter-PMC chromatin transfer through } \\
\text { cytomictic channels, formation of hypo- } \\
\text { and hyperploid PMCs and pycnotic } \\
\text { chromatin, multivalent }\end{array}$ & 21 \\
\hline $\begin{array}{l}\text { Pangi Valley, Chask Bhatori, Chamba district, } \\
\text { Himachal Pradesh, moist shady and grassy slopes on } \\
\text { mountains, , 32 } 55^{\prime} 50^{\prime \prime} \mathrm{N}, 76^{\circ} 37^{\prime} 22^{\prime \prime} \mathrm{E} \text {, Alt.: } 3600 \mathrm{~m}\end{array}$ & 58733 & 7 & $2 \times$ & $\begin{array}{l}\text { Inter-PMC chromatin transfer through } \\
\text { cytomiciric channels, formation of hypo- } \\
\text { and hyperploid PMCs and pycnotic } \\
\text { chromatin }\end{array}$ & 10 \\
\hline $\begin{array}{l}\text { Manali hills, On the way to Rohtang Pass, Kullu } \\
\text { district, Himachal Pradesh, moist shady and grassy } \\
\text { slopes on mountains, } 32^{\circ} 20^{\prime} 49^{\prime \prime} \text {, } 77^{\circ} 13^{\prime} 17^{\prime E} \text {, Alt.: } \\
3280 \mathrm{~m}\end{array}$ & $\begin{array}{l}51304 \\
51305 \\
51306\end{array}$ & 7 & $2 \times$ & $\begin{array}{l}\text { Regular bivalent formation, equal segrega- } \\
\text { tion chromosomes } \\
\text { /chromatids at anaphases I/II and normal } \\
\text { sporads }\end{array}$ & 02 \\
\hline
\end{tabular}

and on average ten slides were scored for stainable pollen. Only well-filled pollen grains with well-stained nuclei were taken as apparently fertile and viable. Photomicrographs of PMCs for chromosomal counts at different stages, meiotic irregularities, sporads and pollen grains were made from the freshly prepared slides using a Nikon Eclipse $80 i$ microscope (Melville, USA).

\section{Results and discussion}

Out of the eight cytologically studied accessions, three accessions depicted PMCs with normal meiosis while in other five accessions meiotic course was aberrant (Tab. 1). All the eight accessions belonging to $H$. astragaloides collected from three geographically different locations have constantly showed the same gametic number of $n=7$. This number was reflected as chromosome associations in PMCs analysed at diakinesis (Fig. 2a) and metaphase-I (Fig. 2b) where seven bivalents were observed. No deviant numbers were observed in any of the normal PMCs.

Among the 203 accepted species of Hedysarum (The Plant List 2013) only $29.06 \%$ have been counted for chromosome number, while about $71 \%$ species still have to be investigated cytologically. In India, three out of nine Hedysarum species have been cytogenetically investigated so far (Rani et al. 2014). The present study accordingly adds the chromosome count for a cytologically unknown species and contributes towards the enrichment of the chromosome database.

In the genus Hedysarum variable chromosome counts $(2 \mathrm{n}=14,16,16+1 \mathrm{~B}, 20,21,28,32,56)$ have been reported (IPCN 2016). Due to such variable reports and lack of chromosomal information, cytological surveys are of great significance in the establishment of the true basic number of the genus Hedysarum. To accomplish such a vital task, it is essential to have information regarding chromosome numbers of as many numbers of species as possible. The information generated from the current study, together with prior published data (Rani et al. 2014), revealed that there are at least two basic numbers $\mathrm{x}=7$ and 8 assumed in the genus
Hedysarum. Chromosome counts are known for 59 species (29.06\%), out these ploidy level in 32 species are based on the $\mathrm{x}=8$ and in 19 species on $\mathrm{x}=7$ while in the rest of the species chromosome counts $(2 \mathrm{n}=14,16)$ are based on both the basic number. However, it would be too premature to predict $\mathrm{x}$ $=8$ (reported for 32 species) to be the ancestral basic number without evolutionary study, phylogenetic study and having chromosome number information on all the known species of the genus. Polyploidy seems to have also played role in the evolution but to a little extent as only seven (11.86\%) species (H. arcticum $2 \mathrm{n}=14,28$, north-east Asia, Russian region of Siberia; $H$. austrokurilense $2 \mathrm{n}=14,16,20,21$, Soviet far east; $H$ dasycarpum $2 \mathrm{n}=16,32$, Siberia, northeastern Yakutia; $H$. gmelinii $2 \mathrm{n}=16$ 28, 56, China, Krasnoyarsk Krai; H. hedysaroides $2 \mathrm{n}=14,28$, Anyui mountains in Russia; $H$. inundatum $2 \mathrm{n}=28$ Tunkinsky Alps, Trans-Baikal region, eastern Sayana, Stanovoye Nagorye Mountains; H. mackenziei 2n = 16, 32, north-east Asia) harbour intraspecific chromosomal variation (IPCN 2016). B-chromosomes were also reported in a diploid species ( $H$. sangilense, $2 \mathrm{n}=16+1 \mathrm{~B}$ ) from southern parts of Siberia by Krasnikova et al. (1983). Such numerical chromosomal variation shows that the genus is in active state of evolution.

Meiosis, an incessant, complex, essential and dynamic process, is categorized by a number of organized cytological events, which end in the reduction of the chromosome number by half and guarantee the constancy of ploidy level in the species after fertilization (Cai and Xu 2007, Fuzinatto et al. 2008). Incidence of typical meiosis in the meiocytes is the prerequisite for the production of balanced gametes. Interference in the meiotic program often leads to harsh effects and generation of abnormalities that can distress the genetic foundation of budding gametes and cause sterility (Brownfield and Köhler 2011). Errors occurring during cell division may not harm the organism but if something goes wrong during meiosis of reproductive cells, the resulting gametes are seriously affected. In current male meiotic investigations, the accession collected from the Manali hills showed normal meiotic course leading to almost $100 \%$ pollen fertility. 
However, the accessions scored from the Manimahesh hills and Pangi Valley depicted cytomixis i.e. inter-PMC transfer of chromatin material at various stages of meiosis-I and II i.e. early prophase-I to sporad stage (Figs. 2c, 2d, 2e, 2f, 2g). Transfer of chromatin material involving 2-5 PMCs existed in $17.11 \%$ cases. Chromatin transfer occurred through narrow cytomictic channels forming chromatin strands (Fig. 2e). In some cases, PMCs were directly fused to facilitate the transfer of chromatin material (Fig. 2h). A few PMCs showed only cytomictic connections without any transfer of chromatin material. The partial transfer of chromatin material resulted into the formation of hypo- and hyperploid PMCs (Figs. 2c, 2g 2h,). Transfer of chromatin material also occurred between the microspores of the same or different sporads (Fig. 2f). Pycnotic chromatin randomly scattered in the cytoplasm was also noticed in some PMCs (Fig. 2h). In addition, accession also showed structural heterozygosity for reciprocal translocations, which is the first report for the species. Out of the 350 analysed PMCs, 20 (5.71\%) showed quadrivalent (ring and chain type) formation at diakinesis (Fig. 2i). The number of chiasma formed per bivalent was 1.70 (4760 chiasma/2800 bivalents). Consequent upon these meiotic disturbances in PMCs up to $21 \%$ of the pollen grains were sterile/unstained (Fig. $2 \mathrm{~m}$ ). In the majority of the PMCs only one bivalent was observed to be associated with nucleolus (Fig. 2j); however, occasionally 2 or 3 bivalents were also seen associated with nucleolus (Figs. 2k, 2l).

Cytomixis is being reported for the first time in this species and also for the genus. Cytomixis, which refers to inter-PMC transfer of chromatin material through cytomictic

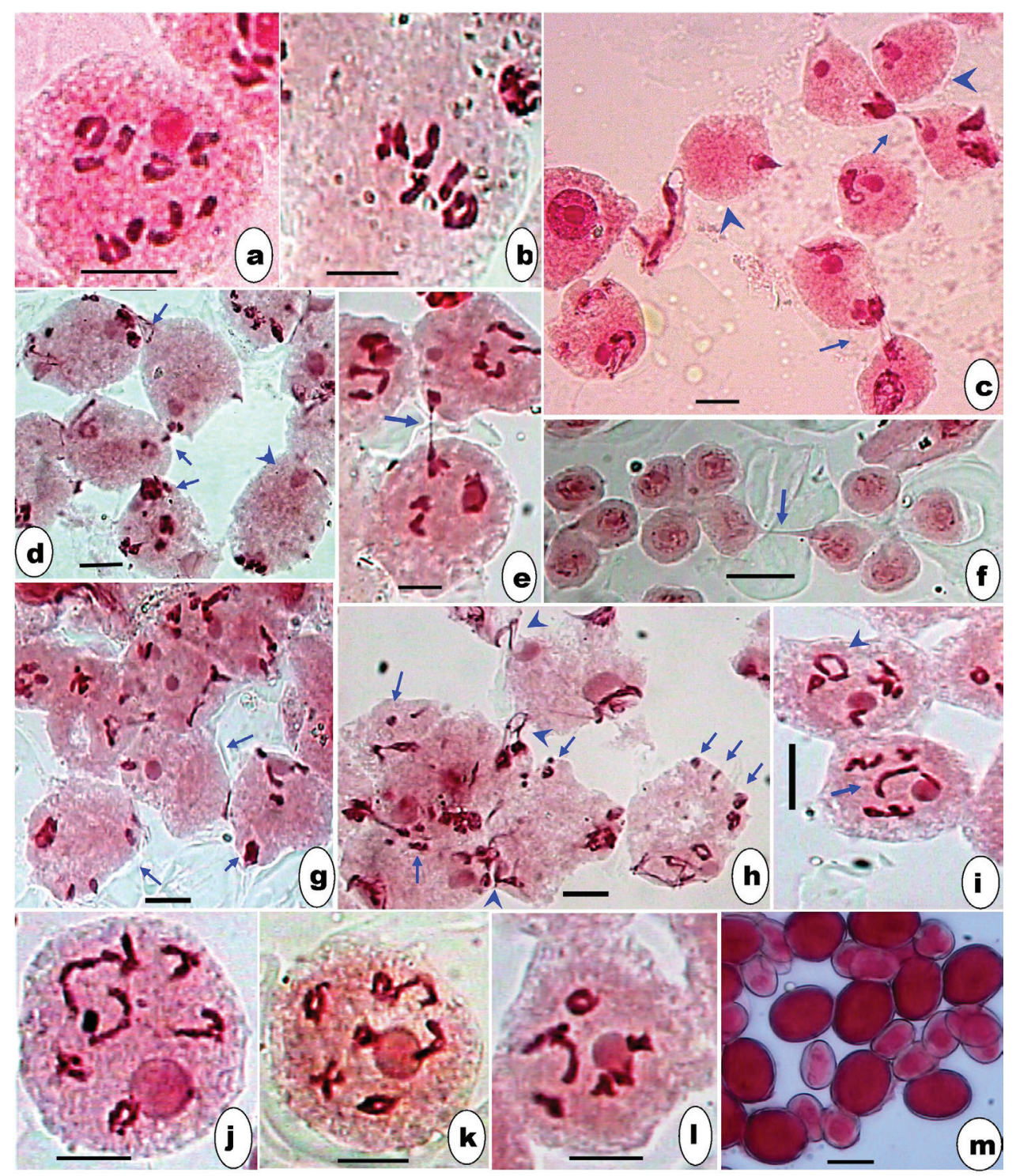

Fig. 2. Pollen mother cells (PMCs) showing meiotic chromosome numbers and meiotic abnormalities, and pollen grains: a) diakinesis, $n$ = 7; b) metaphase-I, $\mathrm{n}=7$; c,d) chromatin transfer (arrows) at early prophase-I, hypoploid PMCs (arrowhead); e) chromatin transfer (arrow) at metaphase-I through narrow cytomictic channels; f) chromatin transfer between microspores of two proximate sporads (arrow); g) hypoploid PMCs (arrows); h), PMCs showing pycnotic chromatin (arrow) and chromatin transfer (arrowhead); i), PMCs showing ring (arrow) and chain type (arrowhead) quadrivalent; j) PMC showing one bivalent associated with nucleolus (arrow); k) PMC showing two bivalents associated with nucleolus (arrows); 1) PMC showing three bivalents associated with nucleolus (arrows); m) apparently fertile (darkly stained) and sterile (shrivelled and lightly stained small sized) pollen grains. Scale bar $=10 \mu \mathrm{m}$ 
channels (intercellular channels) can have serious genetic consequences as it often leads to the formation of aneuploid, polyploid and meiocytes devoid of nucleus, syncytes, various other associated meiotic irregularities, aberrant sporads and pollen sterility (Falistocco et al. 1995, Lattoo et al. 2006, Singhal and Kumar 2008, Kumar et al. 2014, Mursalimov and Deineko 2015). Structural heterozygosity involves the swap of pieces between non-homologous chromosomes known as reciprocal translocations. Such individuals turn out to be heterozygous through reorganization of chromosomal pieces and demonstrate feature and expected modification (Burnham 1956). These structural arrangements can result in numerous chromosomal aberrations, e.g. deletions and duplications. Furthermore such chromosomal aberrations can produce either semi-sterile gametes (Ghaffari et al. 2009) or complete sterility due to reciprocal translocations, e.g. in $\mathrm{Al}$ lium consaguineum (Gohil and Koul 1978) and Allium roylei (Sharma and Gohil 2003). In addition to cytomixis, structural heterozygosity could also be responsible for pollen sterility (Kumar and Singhal 2013, Kumar et al. 2015).

All these anomalies are highly pernicious to reproductive success of such species. Moreover, these abnormalities can even mutate the breeding behaviour by imposing total male sterility and changing the pollination system. The phenomenon of cytomixis has affected the pollen fertility in the current case. Species with narrow ranges of distributions, low levels of diversity and reproductive hindrance are more and more being given high precedence by conservation biologists and government agencies, for the sake of predicting

\section{References}

Ali, S. I., 1977: Papilionaceae. In: Nasir, E., Ali, S. I. (eds.), Flora of West Pakistan, vol. 100, 1-389. Karachi , Pakistan.

Archibald, J. K., Wolf, P. G., Tepedino, V. J., Bair, J., 2001: Genetic relationships and population structure of the endangered Steamboat buckwheat, Eriogonum ovalifolium var. williamsiae (Polygonaceae). American Journal of Botany 88, 608-615.

Aswal, B. S., Mehrotra B. N., 1994: Flora of Lahaul-Spiti: A Cold Desert in North West Himalaya. Bishen Singh Mahendra Pal Singh, Dehra Dun, India.

Baker J. G. 1876. Leguminosae. In: Hooker J. D (ed.), Flora of British India 2. Rev. \& Co. Kent, London.

Belling, J., 1921: On counting chromosomes in pollen mother cells. American Naturalist 55, 573-574.

Brownfield, L., Köhler, C., 2011: Unreduced gamete formation in plants: mechanisms and prospects. Journal of Experimental Botany 62, 1659-1668.

Burnham, C. R., 1956: Chromosomal interchanges in plants. Botanical Review 22, 419-552.

Cai, X., Xu, S. S., 2007: Meiosis-driven genome variation in plants. Current Genomics 8, 151-161.

Chowdhery, H. J., Wadhwa, B. M., 1984: Flora of Himachal Pradesh Vol I. Botanical Survey of India, Howrah, Kolkata, India.

Dhaliwal, D. S. and Sharma, M., 1999: Flora of Kullu District (Himachal Pradesh). Bishen Singh Mahender Pal Singh, Dehra Dun, India.

Falistocco, E., Tosti, T., Falcinelli, M., 1995: Cytomixis in pollen mother cells of diploid Dactylis, one of the origins of $2 \mathrm{n}$ gametes. Journal of Heredity 86, 448-453. enduring goals for conservation programmes. Thus, evaluation of genetic and reproductive potential of such endemic and threatened species from unexplored areas is very significant so that the data generated can be used to develop the future strategy for its conservation. So it is suggested here that such species must be considered at priority during conservation programmes of Himalayan plants. Furthermore, success of any conservation programme depends upon the initial selection of healthy individuals and any mistake at this step can lead to wastage of resources and prove to be futile. Conservation measures should include the collection of germplasm from localities where plants are meiotically stable, in particular, populations showing normal meiosis and high gametic fertility, to ensure good germination and healthy plants for future use. Germplasm from such stable and normal individuals should be given priority for inclusion in a seed bank.

\section{Acknowledgements}

The authors are thankful to the University Grants Commission (UGC), New Delhi, for providing financial assistance under the DRS SAP I, II \& III, ASIST programme, and Dr. D.S. Kothari Postdoctoral Fellowship to the senior author [award letter no. F.4-2/2006(BSR)/13-427/2011(BSR)]. The authors are very grateful to the head of the Department of Botany, Punjabi University, Patiala and Director, Botanical Survey of India, Kolkata, for the necessary laboratory, Herbarium (PUN, BSD) and library facilities.

Fedtschenko, B., 1902: A revision of the Genus Hedysarum. Acta Horticulturae 19, 185-325.

Fuzinatto, V. A., Pagliarini, M. S., Valle, C. B., 2008: Evaluation of microsporogenesis in an interspecific Brachiaria hybrid (Poaceae) collected in distinct years. Genetics and Molecular Research 7, 424-432.

Ghaffari, S. M., Karimzadeh, G., Nageli. A. A., 2009: Occurence of reciprocal translocations in Lathyrus boisserei Sirj (Fabaceae) from Iran. Cytologia 74, 195-199.

Gitzendanner, M. A., Soltis, P. S., 2000: Patterns of genetic variation in rare and widespread plant congeners. American Journal of Botany 87, 783-792.

Gohil, R. N., Koul, A. K., 1978: Structural hybridity in Allium consanguineum. Cytologia 43, 243-247.

IPCN chromosome reports. Missouri Botanical Garden, Missouri, 2016, http://www.tropicos.org/Project/IPCN

Krasnikova, S. A., Krasnikov, A. A., Rostovtzeva, T. S., Chanminchun, V. M., 1983: Chromosome numbers of some plant species from the south of Siberia. Botanicheskii Zhurnal SSSR 68, 827-835 (in Russian).

Kumar, P., Singhal, V. K., 2013: Reduction in chiasma frequency and pollen fertility due to multiple chromosomal associations and univalents in Saxifraga diversifolia from alpine regions of northwest Himalayas (India). Caryologia 66, 120-127.

Kumar, P., 2010: Exploration of cytomorphological diversity in the members of Polypetalae from Lahaul-Spiti and adjoining areas. PhD thesis, Punjabi University, Patiala, Punjab, India, http://hdl.handle.net/10603/2872 
Kumar, P., Rana, P. K., Himshikha., Singhal, V. K., Gupta, R. C., 2014: Cytogeography and phenomenon of cytomixis in Silene vulgaris from cold regions of Northwest Himalayas (India). Plant Systematics and Evolution 300, 831-842.

Kumar, R., Rana, P. K., Himshikha., Kaur, D., Kaur, M., Singhal, V. K., Gupta, R. C., Kumar, P., 2015: Structural heterozygosity and cytomixis driven pollen sterility in Anemone rivularis Buch.-Ham. ex DC. from Western Himalaya (India), Caryologia 68, 246-253.

Lal, K., Kushwaha, A. K. and Chaudhary, L. B., 2014: Taxonomic notes on Hedysarum astragaloides (Fabaceae). Japanese Journal of Botany 89, 230-235.

Lattoo, S. K., Khan, S., Bamotra, S., Dhar, A. K., 2006: Cytomixis imparis meiosis and influences reproductive success in Chlorophytum comosum (Thunb) Jacq. - An additional strategy and possible implications. Journal of Biosciences 31, 629-637.

Levin, D. A., 2002: The role of chromosomal change in plant evolution. Oxford University Press, Oxford.

Marks, G. E., 1954: An acetocarmine glycerol jelly for use in pollen fertility counts. Stain Technology 29, 277.

Mursalimov, S. R. and Deineko, E.V., 2015: How cytomixis can form unreduced gametes in tobacco. Plant Systematics and Evolution 301, 293-1297.

Ohashi, H. and Tateishi, Y., 1975: The genus Hedysarum (Leguminosae) in the Himalayas. Bulletin, University Museum University of Tokyo 8, 363-392.

Pramanik A., 1988. Hedysarum astragaloides Benth. ex Baker. In: Nayar M. P., Shastry A. R. K. (eds.), Red Data Book of Indian plants, vol. 2. Botanical Survey of India, Kolkata, India.
Rani, S., Jeelani, S. M., Kumar, S., Kumari, S., Gupta, R. C., 2014: An overview of chromosome and basic numbers diversity in cytologically investigated polypetalous genera from the Western Himalayas (India). Caryologia 67, 1-24.

Sánchez-Jiménez, I., Hidalgo, O., Canela, M. Á., Siljak-Yakovlev, S., Šolic', M. E., Vallès, J., Garnatje, T., 2012: Genome size and chromosome number in Echinops (Asteraceae, Cardueae) in the Aegean and Balkan regions: technical aspects of nuclear DNA amount assessment and genome evolution in a phylogenetic frame. Plant Systematics and Evolution 298, 1085-1099.

Sanjappa M., 1992: Legumes of India. Bishen Singh Mahendra Pal Singh, Dehra Dun, India.

Sharma, G. and Gohil, R. N., 2003: Cytology of Allium roylei Stearn. I. Meiosis in a population with complex interchanges. $\mathrm{Cy}-$ tologia 68, 115-119.

Singh, H. and Sharma, M., 2006: Flora of Chamba District (Himachal Pradesh), Bishan Singh Mahendra Pal Singh, Dehra Dun, India, India.

Singh, N. P., Singh, D. K., Uniyal, B. P., 2002: Flora of Jammu \& Kashmir, Vol. I. Botanical Survey of India, Kolkata, India.

Singhal, V. K. and Kumar, P., 2008: Impact of cytomixis on the meiosis, pollen viability and pollen size in wild populations of Himalayan poppy (Meconopsis aculeata Royle). Journal of Biosciences 33, 371-380.

Stuessy, T. F., 2009. Plant taxonomy: the systematic evaluation of comparative data, $2^{\text {nd }}$ edn. New York, Columbia University Press.

The Plant List, 2013. Version 1.1. Published on the Internet. Retrieved January 1st, 2016 from http://www.theplantlist.org/ 